ISSN: 2528-9527

E-ISSN : 2528-9535

Yıl Year: 11

Cilt Volume: 17

Sayı Issue: 35

Mart March 2021

Makalenin Geliş Tarihi Received Date. 23/09/2020

Makalenin Kabul Tarihi Accepted Date. 17/03/2021

\title{
Türk ve Rus Akademik Çalışmalarında Yeni Medya Eğitimi Sorunsalı Üzerine Bir Değerlendirme
}

\author{
DOI: $10.26466 /$ opus.798847
}

*

\begin{abstract}
Olga Untila Kaplan*
** Dr. Öğr. Üyes, Istanbul Medipol Üniversitesi, İletişim Fakültesi, Yeni Medya ve İletişim Bölümü, İstanbul/Türkiye

E-Posta: okaplan@medipol.edu.tr

ORCID: $\underline{0000-0003-1525-4989}$

\section{Öz}

Bu çalışma, Türkiye'de ve Rusya'da yeni medya eğitimi üzerine yapılan akademik çalışmalarn tespit edilmeyi ve bu alandaki genel sorunlarının karşılaştırmalı olarak değerlendirilmesini hedeflemektedir. Son yıllarda dünyanin farklı ülkelerinde küresel teknolojik değişimlere ayak uydurabilen nesiller yetiştirme bağlamında tartışılan medya eğitimi alanında, Türkiye'deki bu çabaların Rusya'daki çabalarla ne kadar benzediğini belirli bir açıdan ortaya koyabilmek amacıyla, sektördeki faaliyet gösteren bilirkişilerin görüşlerini de incelenmiştir. Bu çalışma kapsamında bilirkişilerin görüşleri, Türkiye'de ve Rusya'da medya eğitimindeki son durumu, eğilimleri, yabancı tecrübenin önemi, medya eğitimli eğitimcilerin eğitimi ve medya eğitiminin gelişimi için gelecek perspektifleri açıkça ortaya koymaktadır. 1988-2020 yılları arasında yeni medya eğitimine ilişkin yazılan 159 Türk ve 380 Rus olmak üzere toplam 539 akademik çalışma bu araştırmanın amaçl "örnekleme çerçevesini" oluşturmaktadır. Bu kapsamda tespit edilen çalışmaların analizi için "Yeni Medya Ĕ̆itimi Sorunsalı Üçgeni" oluşturulmuştur. Akademik çalışmalar içerik analizi yapılarak, akademik çalışmanın konusu, kavram alanna göre dağılımı, dönemi, türü, yılı ve araştırma problemini kapsayacak şekilde incelenmiştir. Elde edilen veriler, "Yeni Medya Ĕ̆itimi Sorunsalı Üçgeni"nde belirlenen sorun gruplarına dayalı bir şekilde yorumlanmış, tablo ve şekillerle de verilerin gösterimine yer verilmiştir. Araştırma sonucunda, Türkiye'de ve Rusya'da yapılan akademik çalışmalarda yeni medya eğitimi sorunsalı üzerine yapılmış akademik çalışma sayısı oldukç̧a sinırlı olduğu bulunmuştur. Bu çalı̧̧mada, nicel araştırma yöntemleri ele alınarak, Türkiye'deki yeni medya eğitiminin pedagojik ayağında söz konusu olan derslerin kapsadığı alanın sinırlılığı önemli bir eksiklik görülürken, dünyadaki ilk film okuluna sahip olan Rusya'da halen bilgi ve medya kültürünü oluşturma teknolojisine aşina olan uzmanların ciddi bir eksikliği olduğu kaydedilmiştir.

Anahtar Kelimeler: Yeni Medya Eğitimi, Medya Eğitimi, Yeni Medya Eğitimi Sorunlarl, Türk Akademik Çalışmaları, Rus Akademik Çalışmaları

\footnotetext{
* Bu çalışma, 1. Uluslararası Yeni Dünyada iletişim Kongresinde (22-23 Şubat 2020/ Adana) sözel bildiri olarak sunulmuştur.
} 


\title{
An Evaluation on the Problem of New Media Education in Turkish and Russian Academic Studies
}

\begin{abstract}
In this study, to determine academic studies and new media education in Russia and Turkey aims to make a comparative evaluation of the main problems in this area. In recent years, the world's different countries in global technological change in media training areas discussed in the growing context generations can keep up these efforts in Turkey in order to reveal a certain angle it looks like how the efforts in Russia, were also examined the opinions of experts operating in the sector. The opinions of experts within the scope of this study, the current state of media education in Turkey and Russia, trends, the importance of foreign experience, training of media-trained educators and future perspectives for the development of media education clearly reveals. A total of 539 academic studies, 159 Turkish and 380 Russian, written on new media education between 1988 and 2020 constitute the purposeful "sampling framework" of this research. "New Media Education Problem Triangle" was formed for the analysis of the studies determined in this context. Academic studies were analyzed in a content analysis, including the subject of the academic study, its distribution according to the concept area, period, type, year and research question. The data obtained were interpreted based on the problem groups determined in the "New Media Education Problem Triangle", and the display of the data was included in tables and figures. As a result, academic studies in media education in Russia and Turkey made on the question of the number of new academic studies have found to be quite limited. In this study, by considering quantitative research methods, the limitation of the areas covered by the courses mentioned in the pedagogical feet of new media education in Turkey was seen a significant deficiency in the world with the first film school of experts who are familiar with the technology to create the current information and media culture in Russia a serious It was noted that there was a deficiency.
\end{abstract}

Keywords: New Media Education, Media Education, Turkey, Russia, Academic Studies 


\section{Giriş}

Hızlı bir globalleşme sürecine giren yeni medyayı ele alan bilimsel çalışmalar, günümüzde gittikçe önemi artan bir konu olmaktadır. Medya okuryazarlarının sayısının artmasını sağlayan önemli etkenlerden birisi de yeni medya eğitimidir. "Hem genişleyen hem de eş zamanlı olarak birbirlerini iten bir tür paralel uçuş" (Schaffer, 1984, s.19) olarak adlandırılan yeni medya eğitimi, "mümkün görünen ve iletişimin artan önemi nedeniyle çoğu toplum tarafından arzulanan şey, herkese iletişimin doğru kullanımını öğretmenin yeni sorumluluğudur" (Dieuzeide, 1984, s. 81). Ancak bugün pek çok ülkelerin eğitim sistemi dijital ekonominin yetkinliklerini oluşturmuyor, yeni teknolojilerin yeteneklerini kullanmıyor. İnternet ve sosyal medya kullanımında hizlı bir artış gözlemlenmesine rağmen, Türkiye ve Rusya yeni medya eğitimi alanında istisnai bir başarı örneği oluşturmamaktadır.

McLuhan'a göre elektronik teknoloji çağında toplumsal sistemin içindeki çeşitli alt-sistemler karşılıklı etkileşim içinde bulunduklarından ve çift yönlü akışlı bir enformasyona bütün alt-sistemler gereksinim duyduklarından, günümüz toplumlarındaki çözümlenmemiş sorunların pek çoğunun çözümlenmesi artık hem olanaklıdır, hem de gereklidir (Yengin, 2014, s. 57). Yeni medya eğitimi sorunsalı böyle bir zeminden kaynaklanıyor olabilir mi? Teknolojik gelişmelerin dizisini oluşturan Web 1.0, Web 2.0, Web 3.0 ve Web 4.0 dönemlerin kısa analizi PISA sonucunun genel yorumuyla ilişkilendirerek yeni medya eğitimi sorunsalı için önemli bir ipucu olabileceğini düşünülmektedir.

Etkileşim, değişim ve dönüşüme kapalı bir teknoloji dönemi ifade eden Web 1.0'in Web 2.0'a evrilmesiyle bilginin "etkileşimli" bir şekilde üretilmesi ve paylaşılması mümkün kılmıştır. Web 3.0'ün devreye girmesiyle birlikte insanlar bireyselleştirilmiş arama sonuçları sunabilen bir teknolojiden faydalanma imkânına sahip olmuşlardır. Küreselleşmenin bir sonucu olan Web 4.0 insanlara bilgisayara yapabildikleri her şeyi internet ortamında yapabilme özgürlüğü sunmakla beraber gerçek yaşamın sanal ortama taşınma özelliğine sahip bir teknolojidir. Bu bağlamda Ahmet İnam'ın "teknoloji bizimdir, anlayabilirsek, yorumlayabilirsek, bizim olacaktır" saptamasından hareketle yeni iletişim teknolojileri ile kurduğumuz ilişkinin boyutu da anlama ve yorumlama yetimize kalmaktadır (Genel, 2015, s. v). Bunu yapabilme gücüne sahip 
olup olmadığımıza küresel bir nitelik taşıyan son PISA testin sonucu açıklamaktadır. Sonuca göre, son yıllarda dünyada okuryazarlık seviyesinde ciddi bir azalma kaydedildiği görülmektedir (Untila Kaplan, 2020, s. 717). Olga Untila Kaplan'ın “Medya Sağlık Okuryazarlığında Küresel Ortaklık Arayışları” isimli çalışmasında beş ülkenin dijital medyasında yer alan görüşleri incelenmiş ve yapılan analizlerin sonucunda nüfusun okuryazarlık seviyesini etkileyen eğitim ile ilişkili olduğu düşüncesi ortaya konulmuştur (Untila Kaplan, 2020, s. 723).

Günümüz dünyasında ülkeler arası rekabette bilgi üreten toplumların diğer ülkelere göre daha önde olduğu gerçeği, bu rekabette öne geçmek isteyen ülkelerin nitelikli insan yetiştirebilmek için eğitim politikalarını gözden geçirmelerine ve eğitim sistemlerini geliştirmelerine neden olmuştur (Korucu, A. T., 2016, s. 380). Yeni oluşturulan bu sistemler iletişim ve eğitim teknolojileri ekseninde yeniden yapılandırılmaktadır. 21. yüzyılın dünyasında tüm ülkelerin çabaları toplumun bilgi ve eğitim ihtiyaçlarını karşılayan yeni sosyoteknik yapılarının oluşturulması ve içinde bulunduğumuz küresel süreç içerisinde ortaya çıkan sorunlarının çözüme kavuşturulmasına odaklanmıştır.

Bu bilgilerden yola çıkarak, bu çalışmada Türkiye'de ve Rusya'da yeni medya eğitimindeki birbirinden etkilenen ve dijital dönüşüm sürecinde belirginlik kazanan sorunlarının üç ana başlık altında incelenmesi amaçlanmıştır:

1. Yeni medya okuryazarlığı eğitimi;

2. Yeni nesil (iletişim/eğitim) teknolojileri;

3. Yeni eğitim sistemleri.

Yeni medya eğitimi sorunsalı oluşturan bu üçgen, dijital dünyada bireylerin yeni medya okuryazarlığı eğitimindeki kilitlenen sorunları yansıtmaktadir. 


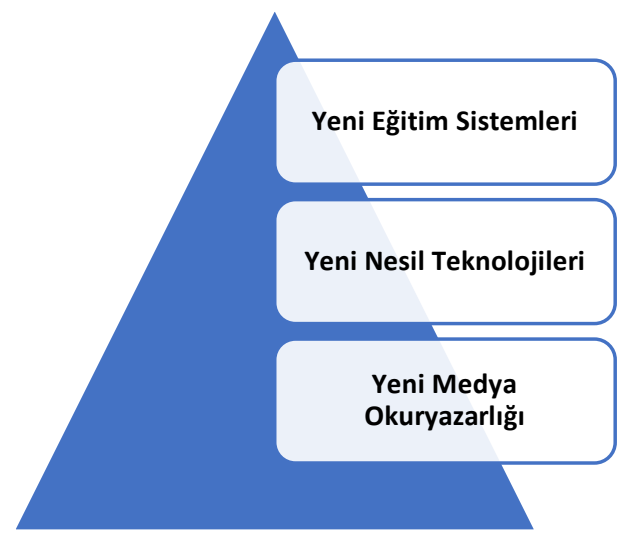

Şekil 1. Yeni Medya Eğitimi Sorunsalı Üçgeni

İnternet tabanlı yeni nesil teknolojileri ile donatılan medya ve eğitim sistemleri gerçeğin ötesinde kurulan bir dünyaya ayak uydurmak maksadıyla yeni vasıflı üre-tüketici insan profili yaratmayı amaçlamaktadır. Bu süreçte yaşanan sorunlar Türk ve Rus bilimsel çalışmalarında tartışılmıştır.

Yeni medya eğitimi üzerinde ulusal seviyede bir takım araştırmalar yapılmış olmasına rağmen, Türk ve Rus akademik çalışmalarında yeni medya eğitimi sorunsalı gibi konu üzerine yeterli çalışma ve inceleme yapılmadığı görülmektedir. Bu çalışma, Türkiye'de ve Rusya'da yeni medya eğitimi üzerine yapılan akademik çalışmaları tespit edilmeyi ve bu alandaki genel sorunlarının karşılaştırmalı olarak değerlendirilmesini hedeflemektedir.

\section{Yöntem}

$\mathrm{Bu}$ araştırma betimsel tarama modelinde bir araştırmadır. Betimsel araştırmalar; olayların, objelerin, varlıkların, kurumların, grupların ve çeşitli alanların ne olduğunu betimlemeye, açıklamaya çalışır. Bu sayede onları iyi anlayabilme, gruplayabilme olanağı sağlanır ve aralarındaki ilişkiler saptanmış olur. Betimsel tarama modelinde bilimin gözlem, kaydetme, olaylar arasındaki ilişkileri tespit etme ve kontrol edilen değişmez ilkeler üzerinde genellemelere varma nitelikleri söz konusudur. Yani bilimin tasvir fonksiyonu ön plandadır (Selçuk, Palancı, Kandemir ve Dündar, 2016, 432). Yapılan bu çalişmada da Türkiye'de Yükssek Öğretim Kurulu (YÖK) Ulusal Tez Merkezi'nin ve Rusya'daki Bilimsel Elektronik Tez ve Özetler Kütüphanesi'nin dijital sayfalarında yer alan 1988-2020 yılları arasında yazılmış olan yüksek 
lisans ve doktora tezleri çeşitli değişkenler açısından analiz edilerek açıklanmaya çalışılmıştır. 1988 yılı Türkiye' de yeni medya eğitimi üzerinde ilk akademik çalışmanın yazıldığı yılıdır. 1988 yılından 2020 yılına kadar konuyla ilgili Türk ve Rus ulusal dijital platformlarda yer alan tezlerin irdelenmesi araştırmanın sınırlılığını oluşturmaktadır.

Araştırmada literatür taraması yapılmış ve daha sonraki aşamadaysa, çalışmanın amacına uygun olarak içerik analizine başvurulmuştur. Weber'e göre içerik analizi, metinden çıkarılan geçerli yorumların bir dizi işlem sonucu ortaya konulduğu bir araştırma tekniğidir. Bu yorumlar, mesajın göndereni, mesajın kendisi ve mesajın alıcısı hakkındadır (Koçak ve Arun, 2006, s. 22).

\section{Çalışmanın Hedefleri Doğrultusunda Veri Toplama Teknikleri}

Hedef 1-: Alanda genel sorunların karşılaştırmalı olarak değerlendirilmesi doğrultusunda Türk ve Rus dijital platformlarda yer alan yeni medya eğitimi sorunsalı konulu akademik çalışmaların tespiti yapmaktır.

Veri Toplama Tekniği-1: Akademik çalışmaların yer aldığı dijital platformları seçip Türkçe ve Rusça dilinde "yeni medya eğitimi" ve "yeni medya eğitimi sorunları" anahtar kelimeleri ile tarama yapılmıştır. Elde edilen sonuçları sınıflandırıp nicel araştırma yöntemi ile tablolaştırılmıştır.

Veri Toplama Tekniği-2: Kapsamlı bir inceleme yapmak için seçtiğimiz dijital platformlarda tarama yapıldığı anahtar kelimelerinin yelpazesini "yeni medya eğitimi sorunsalı üçgeni"nde yer alan başlıklara göre genişletilmiştir. Bu çerçevede ilgili platformlarda tarama "yeni medya okuryazarlığı eğitimi", "yeni iletişim teknolojileri", " yeni eğitim teknolojileri" ve "yeni eğitim sistemleri" anahtar kelimeleri ile yapılmıştır.

Hedef 2- Küresel teknolojik değişimleri ışı̆̆ında yeni nesiller yetiştirme çabaları değerlendirebilmek için yeni medya eğitimi sorunsalı üzerine Türk ve Rus bilirkişilerin görüşlerini kıyaslayarak ortaya koymaktır.

Veri Toplama Tekniği: Türk ve Rus bilirkişilerin görüşlerini ortaya koyabilmek adına literatür taraması yöntemi kullanarak, sektörün gelişiminde önemli katkılarda bulunan bilim adamlarının çalışmalarından yararlanılmıştir. 


\section{Evren ve Örneklem}

İçerik analizinde evren, dört temel yaklaşımla sınırlanabilir (Koçak ve Arun, 2006, s. 24); nerede (Türkiye ve Rusya), ne zaman (1988-2020), hangi araciyla (yüksek lisans ve doktora tezleri, yüksek lisans ve doktora tezlerin genişletilmiş özetleri) ve hangi konuda (yeni medya eğitimi sorunları). Araştırmada örneklem grubuna girecek akademik çalışmalar amaçlı örnekleme yöntemi kullanılarak alınmıştır. Örneklem grubunu; 159 Türk ve 380 Rus olmak üzere toplam 539 akademik çalışması oluşturmaktadır.

\section{Araştırmanın Stnırlılıkları}

Türkiye'de Yüksek Öğretim Kurulu (YÖK) Ulusal Tez Merkezi'nin (https://tez.yok.gov.tr/UlusalTezMerkezi/) ve Rusya'daki Bilimsel Elektronik Tez ve Özetler Kütüphanesi'nin (dissercat.com) dijital sayfalarında yer alan yüksek lisans ve doktora tezleri incelenmesi ile sinırlıdır.

\section{Verilerin Analizi}

İçerik analizinin temel amacını toplanan verileri açıklayabilecek kavramlara ve ilişkilere ulaşmak olarak ifade eden Yıldırım ve Şimşek'e (2006) göre toplanan verilerin önce kavramsallaştırılması daha sonra da ortaya çıkan kavramlara göre mantıklı bir biçimde düzenlenmesi ve buna göre veriyi açklayan temaların saptanması gerekmektedir (Sert, Kurtoğlu, Akıncı ve Seferoğlu, 2012, 353). Rus araştırma geleneğinde, içerik analizi, tanımlanan saylsal kalıpların daha sonra anlamlı bir şekilde yorumlanması amacıyla metinlerin ve metin dizilerinin nicel bir analizi olarak tanımlanır (Пашинян, 2012, s. 13).

Bu araştırmada ilk önce "yeni medya eğitimi sorunsalı üçgeni" oluşturulmuş ve tespit edilen Türk ve Rus akademik çalışmalarında genel sorunları "üçgen"deki yer alan yeni medya okuryazarlığı, yeni nesil teknolojileri ve yeni eğitim sistemleri gibi gruplara göre farklılaşıp farklılaşmadığı karşılaştırılmıştır. Daha sonra içerik analizi tekniğiyle analiz edilen yeni medya eğitimi sorunsalı ülke bazında ne tür değişiklikler ve benzerlikler gösterdiğini ortaya konmuştur. Son olarak medya eğitimindeki son durumu, eğilimleri, yabancı tecrübenin önemi, medya eğitimli eğitimcilerin eğitimi ve medya eğitiminin 
gelişimi için gelecek perspektifleri ortaya koyabilmek için Türk ve Rus bilirkişilerin görüşleri incelenmiştir.

\section{Bulgular}

Araştırmanın bulgular bölümünde, Türk ve Rus dijital platformlarda yer alan yeni medya eğitimi sorunsalı konulu akademik çalışmaları üzerine yapılan analizleri ve elde edilen bulgular bulunmaktadır. "Yeni medya eğitimi sorunsalı üçgeni" ndeki sorun gruplarına göre analiz edilen akademik çalışmalarının farklı değişkenler açısından irdelenmiş ve yeni medya eğitimi sorunsalı oluşturan unsurları karşılaştırma yöntemi ile çeşitli başlıklar altında açıklanmıştır. Bunlar arasında en önemlileri sırasıyla; öğrencilerin yeni medya okuryazarlığ 1 düzeyleri, öğretmenlerin yeni medya okuryazarlığı düzeyleri, yeni eğitim teknolojileri, uzaktan eğitim sisteminde yeni iletişim teknolojileri, öğretmenlerin multimedya kullanımı ve medya eğitimidir.

Analizlere geçmeden önce akademik çalışmaların kavram alanlarına ilişkin betimsel istatistikler tablo 1'de sunulmuştur.

Tablo 1. Akademik Çalışmaların Kavram Alanlarına Göre Dağılımı

\begin{tabular}{lcc}
\hline Kavram Alanı & $\begin{array}{c}\text { Tarama Sonucu } \\
\text { Türkiye }\end{array}$ & $\begin{array}{c}\text { Tarama Sonucu } \\
\text { Rusya }\end{array}$ \\
\hline Yeni Medya & 255 & 17316 \\
\hline Yeni Medya Eğitimi & 0 & 386 \\
\hline Yeni Medya Eğitimi Sorunları & 0 & 380 \\
\hline Yeni Medya Okuryazarlığı & 6 & 96 \\
\hline Yeni Medya Okuryazarlığı Ĕ̆itimi & 0 & 57 \\
\hline Yeni İletişim Teknolojileri & 58 & 12348 \\
\hline Yeni Eğitim Teknolojileri & 2 & 48895 \\
\hline Yeni Eğitim Sistemleri & 0 & $\mathbf{2 6 8} \mathbf{1 7 9}$ \\
\hline Toplam Akademik Çalışma & $\mathbf{3 2 1}$ & \\
\hline
\end{tabular}

Tabloda yer alan kavram alanlarla ilgili sonuçları elde etmek için YÖK'ün Ulusal Tez Merkezi'nin ve Rusya'daki Bilimsel Elektronik Tez ve Özetler Kütüphanesi'nin dijital sayfalarına doğrudan girilerek anahtar kelimeleri ile tarama yapılmıştır. Tarama sonucunda elde edilen sonuçlar, Türkiye'de ve Rusya'da her kavramla ilgili yapılan akademik çalışmalarının sayısını ifade etmektedir. Tablodan anlaşıldı̆̆ı gibi, yeni medya eğitimi sorunsalını açıklayan bu sekiz anahtar kavramın tümü Rus akademik çalışmalarında rastlamak mümkünken, Türk araştırmalarında "yeni medya eğitimi", "yeni 
medya eğitimi sorunları", "yeni medya okuryazarlığı eğitimi" ve "yeni eğitim sistemleri" kavramlar konusunda hiçbir sonuç elde edilememiştir. Türkiye'de "yeni medya" kavramı ele alan yüksek lisans ve doktora tez sayısının 300'e varmazken, Rusya' da akademik çalışma sayısı 17 bini aştı. Dissercat sisteminde yer alan yeni eğitim sistemleri ile ilgili araştırmaların sayısı 188 701'dir ve en fazla araştırma yapılan konularından biridir.

\section{Türk ve Rus Akademik Çalışmalarnın İncelenmesine İlişkin Bulgular}

Tablo 2. Türkiye'de "Yeni Medya Okuryazarlı̆̆ı" Konulu Akademik Çalışmalar

\begin{tabular}{llll}
\hline Y11 & Tez Türü & Konu & Tez Sayısı \\
\hline 2011 & Doktora & İletişim Bilimleri & 1 \\
\hline 2015 & Doktora & Gazetecilik & 1 \\
\hline 2015 & Yüksek Lisans & Eğitim ve Öğretim & 2 \\
\hline 2017 & Yüksek Lisans & İletişim Bilimleri & 1 \\
\hline 2019 & Yüksek Lisans & İletişim Bilimleri & 1 \\
\hline Toplam: & & & 6 \\
\hline
\end{tabular}

Türkiye'de "yeni medya okuryazarlığı" kavramı üzerine yapılan 6 akademik çalışma tespit edilmiştir. Mevcut çalışmalar ağırlıklı olarak iletişim bilimleri alanında yapılmıştır. Eğitim ve öğretim alanında 2 akademik çalışma yapıldığı gözlemlenmiştir.

Tablo 3. Türkiye'de "Yeni İletişim Teknolojileri" Konulu Akademik Çalışmalar

\begin{tabular}{lll}
\hline Alan & Dönem & Tez Sayıs \\
\hline Halkla İlişkiler & $2004-2020$ & 14 \\
\hline İletişim Bilimleri & $1988-2019$ & 11 \\
\hline Gazetecilik & $1995-2014$ & 8 \\
\hline Radyo Televizyon & $1996-2019$ & 8 \\
\hline Eğitim ve Öğretim & $1999-2017$ & 2 \\
\hline Diğer & $2002-2018$ & 15 \\
\hline Toplam: & & $\mathbf{5 8}$ \\
\hline
\end{tabular}

"Yeni iletişim teknolojileri" anahtar kelimeleri ile yapılan tarama sonucunda 40 yüksek lisans ve 18 doktora tezi olmak üzere toplam 58 akademik çalışma tespit edilmiştir. Çoğu araştırma halkla ilişkiler ve iletişim bilimleri alanlarında yapıldı̆̆ı gözlemlenmiştir. Eğitim ve öğretim alanında ise, yeni iletişim teknolojileri ele alan sadece 2 akademik çalışma tespit edilmiştir. Diğer akademik çalışmalar başta siyasal bilimler ve bilim ve teknoloji olmak üzere bankacılık, bilgisayar mühendisliği bilimleri, kamu yönetimi, sağlık kurumları yönetimi, sosyoloji ve müzik gibi alanlarda yapılmıştır. Akademik çalışmaların yapıldığı dönemleri incelendiğinde; iletişim bilimleri alanında 
araştırmaların hazırlandığı 1988 ve 2019 yıllarını kapsadığını görülmektedir. Bu dönemin geniş bir aralığı kapsaması, yeni iletişim teknolojilerini mercek altına alan araştırma faaliyetinin sürekliliğinin bir göstergesi olarak ifade edilebilir. Halkla ilişkilerde yeni iletişim teknolojilerini inceleyen bilimsel çalışmalar geç tarihlerde yapılmaya başlandığı hâlde, sayı bakımından ilk sırada yer aldığı tespit edilmiştir. Tablodan da anlaşıldığg gibi, aynı nitelikte yenilikleri takip eden çalışmalar eğitim ve öğretim alanında yapılmamıştır.

Tablo 4. Türkiye'de "Yeni Eğitim Teknolojileri" Konulu Akademik Çalışmalar

\begin{tabular}{clll}
\hline Yıl & Tez Türü & Konu & Tez Sayısı \\
\hline 2002 & Yüksek Lisans & Eğitim ve Ö̆gretim & 1 \\
\hline 2002 & Yüksek Lisans & Mimarlık & 1 \\
\hline Toplam: & & & $\mathbf{2}$ \\
\hline
\end{tabular}

Yeni eğitim teknoloji ile ilgili ulaşılan veriler yeterli olmadığı için konuyu zenginleştirmek amacıyla, "eğitim teknolojileri” anahtar kelimeleri ile tarama yapılmıştır.

Tablo 5. Türkiye'de "Eğitim Teknolojileri" Konulu Akademik Çalışmalar

\begin{tabular}{llc}
\hline \multicolumn{1}{c}{ Alan } & Dönem & Tez Sayısı \\
\hline Eğitim ve Öğretim & $2002-2019$ & 29 \\
\hline Blgisayar Müh. Bilimleri & $1999-2008$ & 2 \\
\hline Mimarlı & $2002-2012$ & 2 \\
\hline Işletme & 2012 & 1 \\
\hline Kamu Yönetimi & 2014 & 1 \\
\hline Toplam: & & 35 \\
\hline
\end{tabular}

"Eğitim teknolojileri” anahtar kelimeleri ile yapılan taramanın sonucunda 35 araştırma tespit edilmiştir. Akademik çalışmalarının çoğunu eğitim ve öğretim alanında yapıldığı gözlemlenmiştir. Türkiye'de ilk defa eğitim teknolojileri konusunu ele alan akademik çalışma 1999 yılında bilgisayar mühendisliği bilimleri alanında yapılmıştır. Üç sene sonra eğitim teknolojileri ile ilgili yapılan araştırma sayısının arttığı gözlemlenmiştir. 2019 yılına kadar eğitim ve öğretim alanında hazırlanmış olan tezlerin sayısı 29'a ulaşmışken, iletişim bilimleri alanında hiçbir akademik çalışma yapılmadığını tespit edilmiştir.

Tablo 6. Türkiye'de "Eğitim Sistemleri" Konulu Akademik Çalışmalar

\begin{tabular}{lll}
\hline Alan & Dönem & Tez Sayıs \\
\hline Eğitim ve Öğretim & $1991-2019$ & 46 \\
\hline Blgisayar Müh. Bilimleri & $2009-2019$ & 5 \\
\hline Alman Dili ve Edebiyatı & $1998-1999$ & 2 \\
\hline Siyasal Bilimler & 2007 & 1 \\
\hline Bilim ve Teknoloji & 2008 & 1 \\
\hline
\end{tabular}




\begin{tabular}{lcc}
\hline Kimya & 1998 & 1 \\
\hline Spor & 2019 & 1 \\
\hline Çalışma Ekonomisi & 2019 & 1 \\
\hline Toplam: & & $\mathbf{5 8}$ \\
\hline
\end{tabular}

Yeni eğitim sistemleri ile ilgili ulaşılan sonuçlar yeterli olmadığı için analiz edilebilir verilere ulaşmak amacıyla sistemde "eğitim sistemleri" anahtar kelimeleri ile tarama yapılmıştır. "Eğitim sistemleri" anahtar kelimeleri ile yapılan tarama sonucunda toplam 58 sonuç elde edilmiştir. Eğitim ve öğretim alanında yapılan ilk akademik çalışma 1991 tarihlidir. Aradan geçen 28 yıl içinde bu alanda eğitim sistemleri ile ilgili hazırlanan akademik çalışmaların sayısı 46'ya ulaşmıştır. Bu tezlerin 5'i doktora 41'i yüksek lisans tezi, Türkiye'de eğitim sistemi değişimini yansıtan zengin bir akademik kaynağı oluştuğu düşünülmektedir. Bilgisayar mühedisliği bilimleri, siyasal bilimleri, çalışma ekonomisi, kimya ve spor gibi alanlarda eğitim sistemlerin de inceleme konusu olmuştur.

Rus İnterneti'ndeki en büyük bilimsel araştırmaların kataloğu olan "disserCat" dijital platformunda yeni medya eğitimi ile ilgili yapılan akademik çalışmaların yeterli olduğu sonucuna ulaşılmıştır. Bu nedenle "yeni medya eğitimi sorunsalı üçgeni"ndeki yer alan sorun grupları konuyu detaylı bir şekilde ele alınmasına yönelik yardımcı öğeler olarak değerlendirilmesi karar verilmiştir.

Tablo 7. Rus Çalışmalarda "Yeni Medya Eğitimi" Alt Konu Dağılımı

\begin{tabular}{ll}
\hline Nitelikli Öğrenci Konu Grubu & Nitelikli Öğretmen Konu Grubu \\
\hline Eleştirel Düşünme Becerileri & Öğretmenlik Mesleği Yeterlilikleri \\
\hline Medya Yeterliliği & Medya Yeterliliği \\
\hline Bilgisayar Okuryazarlığı & Medya Kültürü \\
\hline Görsel Okuryazarlığı & Akmeolojik Yeterliliği (Bütünleştirici Kişilik Özelliği) \\
\hline İletişim Becerileri & Bilgi ve Teknoloji Okuryazarlığ1 \\
\hline Medya Kültürü & Kültürel Değerlere Duyarlı Pedagoji Yeterliği \\
\hline Etnik Gruplar Arasındaki Hoşgörü & $\begin{array}{l}\text { İleri Düzeyde Kuramsal, Metodolojik ve Olgusal Bil- } \\
\text { giye Sahip Olması }\end{array}$ \\
\hline
\end{tabular}

"disserCat" dijital platformunda "yeni medya eğitimi" anahtar kelimeleri ile yapılan tarama sonucunda 386 sonuç bulunmuştur. Yeni medya eğitimi alanında araştırılan alt konuların çoğu nitelikli öğrencinin ve nitelikli öğretmenin yetiştirilmesi ile ilgili olduğu tespit edilmiştir. Araştırmaların çoğunu genel pedagoji, pedagoji ve eğitim tarihi, gazetecilik, öğretim ve eğitim teorisi 
ve metodolojisi, meslekî eğitim teorisi ve metodolojisi üzerine odaklandı̆̆1 gözlemlenmiştir.

İncelenen çalışmalar Rusya'da eğitim sistemindeki tüm kademelerini kapsamaktadır. Bu çalışmalardan üç tanesi ülkede yeni medya eğitimi alanında mevcut durumu ve özellikle lisans düzeyinde nitelikli gazeteci yetiştirilmesine olan önemi açıkça vurgulamaktadır:

1. İrina Fateeva (2008). "Rusya'da Gazetecilik Eğitimi: Kuramı, Tarihi ve Modern Uygulaması" ("Журналистское образование в России: теория, история, современная практика")

2. Tatiana Vladimirova (2015). "Rusya'da Yüksek Öğrenimde Gazetecilerin Meslekî Eğitiminin Didaktik Kavramı" (“Дидактическая концепция профессиональной подготовки журналистов в высшей школе России")

3. Anna Kantor (2010). "Modern Koşullarda Öğrencilerin Bilgi Kültürün Gelişmesini Etkileyen Bir Faktör Olarak Televizyon Eğitimi” (“Телевизионное образование как фактор развития информационной культуры учащейся молодежи в современных условиях")

"Yeni medya eğitimi sorunları" anahtar kelimeleri ile yapılan tarama sonucunda toplam 380 sonuç elde edilmiştir. Tespit edilen toplam çalışmalardan sadece 63'ünde yeni medya eğitimi ile ilgili sorunları içindekiler kısmında alt başlık olarak verilmiştir. "Yeni medya eğitimi sorunsalı üçgeni”ne göre değerlendirilen bu sorunlar, 63 araştırmadan 41'nde medya okuryazarlığı, 15'nde eğitim sistemleri ve sadece 7'sinde iletişim ve eğitim teknolojileri bağlamında irdelenmiştir.

Yapılan detaylı inceleme göstermiştir ki, alanla ilgili problemleri doğrudan incelenen ve ana başlığ 1 "sorun" kelimesini içeren sadece 2 akademik çalışma bulunmuştur. Bu başlıklarda "yeni" kelimesinin kullanılmayan bir kelime olmasından dolayı dikkat çekmektedir.

Tablo 8. Rusya'da "Yeni Medya Eğitimi Sorunlan" Konulu Akademik Çalışmalar

\begin{tabular}{|c|c|c|}
\hline Y1l & Yazar & Konu \\
\hline 2006 & Elena Hudoleyeva & $\begin{array}{l}\text { “Almanya ve Rusya'da Modern Medya Eğitiminin Pedago- } \\
\text { jik Sorunları (Yirminci Yüzyılın Sonu Yirmi Birinci Yüzyılın } \\
\text { Başı)” (“Педагогические проблемы медиаобразования в } \\
\text { ФРГ и в России на современном этапе: Конец XX - } \\
\text { начало XXI вв.") }\end{array}$ \\
\hline 2011 & Anna Konstantinova & $\begin{array}{l}\text { "Medya Teknolojilerin Felsefi Sorunları” (“Филосовские } \\
\text { проблемы медиатехнологий”) }\end{array}$ \\
\hline
\end{tabular}




\section{Türk ve Rus Akademik Çalışmalarında Yeni Medya Eğitimi Sorunsalının İn- celenmesine Yönelik Bulgular}

Türk akademik çalışmalarında yeni medya eğitimi sorunsalı oluşturan unsurlar izleyen başlıklar altında açıklanmaktadır:

Medya Okuryazarlığı Dersi: “Medya okuryazarlığı dersinin sosyal bilgiler öğretmenleri mi yoksa iletişim fakültesi mezunlarının mu vermesi gerektiği önemli tartışma konularından bir tanesidir." (Hansu, 2019, s. 46). "Medya Okuryazarlığı dersinden TEOG sınavında soru çıkmaması, dersin seçmeli olması ve öğrencilerin dersi ciddiye almaması öğretmenlerin bu dersi gereksiz görmelerindeki önemli sebepler olduğu düşünülmektedir." (Işkın, 2015, s. 96).

Medya Okuryazarlığı Kitabı: “Bu önemli öğretim kaynağını yalnızca çevrimiçi olarak kullanılabilmektedir. Bu durum ironiktir çünkü medya okuryazarlığı, yeni medya araçları ve bunların kullanımı hakkında temel bilgiler içeren bir ders kitabı bu." (Göysarı, 2016, s. 56).

Öğrencilerin Yeni Medya Okuryazarlı̆̆ı Düzeyleri: “Üniversite öğrencilerinin yeni medya okuryazarlık düzeyleri ortalamanın üzerindedir ve bu düzeylerin yükseltilmesi insanlara 21. yüzyılda problem çözme yeteneklerini geliştirmeyi sağlayacaktır." (Yavuz, 2018, s. 43).

Öğretmenlerin Yeni Medya Okuryazarlığı Düzeyleri: “Etkileşimli tahta kullanma amaçlarından biri olarak belirtilen öğrencilerin dikkatini çekme ve onları güdüleme ile e-içerikleri öğrencilere sunma öğretmen görüşlerinin ortalama olarak bazen düzeyinde kaldığı görülmektedir." (Çağlar, 2012, s. 120).

Öğretmen-Öğrenci Etkileşimi: “Günümüz eğitim dünyasında alternatif bir yaklaşım olan eleştirel pedagoji, baskıdan arınmış bir eğitim ortamını ve eğiten ile eğitilen arasında hiyerarşik ilişkilerin ortadan kaldırılmasını esas almaktadır." (Görgülü Aydoğdu, 2015, s. 102).

Yeni Ĕ̆itim Teknolojileri: “Eğitime yansımayan teknolojinin toplumun öteki katmanlarında etkin olarak kullanılır hale gelmesi beklenemez. Bu nedenle, sanal üniversite uygulaması, en kısa zamanda, ulusal bilim ve teknoloji politikasının bütünlüğünde, bir "milli proje" olarak ele alınmalıdır." (Karasar, 
1999). “Eğitim teknolojilerine ilgili olmasına rağmen öğretmenlerin büyük çoğunluğu (\%66) kendilerini eğitim teknolojilerini kullanma konusunda orta veya daha alt düzeyde yeterli olarak değerlendirmişlerdir. Bunun yanı sıra öğretmenlerin yüzde 75'i eğitim teknolojisi ilgili bilimsel yayınları takip etmede kendilerini orta ve daha alt düzeyde değerlendirmişlerdir. Bu sonuç, öğretmenlerimizin bilimsel yayınları yeterince takip etmediklerini göstermektedir." (Hacısalihoğlu, 2008, s.70). "Türkiye'de teknoloji eğitiminin önemi ve niteliği anlaşılmış değildir. Bu eğitime, günümüzde de çoğu durumda, teknoloji kavramından uzakta, geleneksel bir anlayışla bakılmakta; teknoloji çağında teknoloji kültüründen yoksun bir işleyişs sürmektedir. Bunun önemli nedenlerinden birisi, okul yönetici ve denetleyicilerinin konuya yabancı olmaları; ikincisi ise, alanda görevli öğretmenlerin eğitim yetersizliğidir. Öğretmen yetiştirmenin nicelik ve nitelik olmak üzere iki ana boyutu vardır. Türkiye'deki geçmiş örnekler göstermektedir ki, niteliği görmezden gelerek sadece nicelik boyutunu öne çıkaran uygulamalar, öğretmen sorununu tek boyutlu ele alan uygulamalardır. Bu uygulamalar, eğitim kalitesini geliştirmeden çok, geriye götüren etkiler yaratmaktadır. Böylece, biçimsel olarak öğretmen gereksinimi karşılanmış görünürken; sisteme giren niteliksiz işgücü, eğitim sisteminin ürününün de niteliksiz olmasına yol açmaktadır. Bu bakımdan, teknoloji eğitiminde ihtiyaç duyulan öğretmen gereksiniminin karşılanmasında nicelik kadar nitelik boyutu üzerinde de durulması gereklidir" (Ozan, 2009, s. 22). "Öğretmenlerin sosyal medya alışkanlıkları arttıkça eğitimde teknoloji kullanım durumlarının da artış göstermektedir. Öğretmenlerin sosyal medya alışkanlıklarının, eğitimde teknoloji kullanımına yönelik tutumlarını \%27 oranında açıklayabildiği görülmektedir." (Çobanoğlu, 2018, s. 76). "Dersin hedefleri arasında yer alan öğretim teknolojilerinin kullanımının öğretilmesi, belki de teknolojik yetersizlikler ve nitelikli öğretim elemanı eksikliği gibi çeşitli nedenlerden dolayı öğretmen adaylarına kazandırılmasında sorunlar yaşandığı gözükmektedir." (Gegeoğlu, 2014, s. 21). "Mevcut pek çok eğitim sorunu, kullanılan teknolojilere rağmen devam etmekte ise; mevcut teknolojilerin yetersizliği söz konusudur ve çözüm teknolojik yenilenmede aranmalıdır" (Aygün, 2009, s. 3).

Uzaktan Ĕ̆itim Sisteminde Yeni İletişim Teknolojileri: “Yeni iletişim teknolojileri baz alınarak kurulan uzaktan eğitim sisteminde iki farklı problem biçimi ortaya çıkmaktadır. Bunlardan ilki kullanılan yeni iletişim araçları ve bu 
araçlar içindeki yazılımlardan kaynaklanan problemlerdir. İkincisi ise, aktörlerin sistemi kullanım becerilerinden kaynaklanan problemlerdir. Problemin türü ne olursa olsun sistemdeki aksaklıkların aktörlerin genelini etkilediği nadir görülen bir durumdur, çünkü sistemin hata verme olasılığı oldukça düşük düzeydedir. Bu nedenle neredeyse tüm eğitsel aksaklıklar bireysel düzeyde yaşanmakta ve bu durum bireysel verimliliği düşürmektedir. Aktörlerin sürecin verimliliğini arttırmak için gerekli donanıma erişmesi bir zorunluluktur. Her aktör eğitim programlarından önce eğitsel nitelikler konusunda eğitilmelidir." (Elitaş, 2017, 223-224). Yazarı Melih Engin, uygulanan uzaktan eğitim programlarında öğrencilerin beklentilerinin yeterince karşılanamad1ğını (Yeşilay, 2004), öğrencilerin doyum düzeyinin düşük olduğunu (Parlak, 2004), öğrencilerin çeşitli iletişim engelleri ile karşı karşıya bulunduklarını (Akçakoca, 2006), öğrencilerin mezuniyet oranlarının düşük ve ayrılma (dropout) oranlarının oldukça yüksek olduğunu (Latchem ve diğ., 2009), rapor eden çeşitli araştırmalar bulunduğunu belirtmektedir. Konu ile ilgili araştırmalar daha yakından incelendiğinde, bu sorunların sayı ve türünün çok daha fazla olduğu dikkat çekmektedir (Engin, 2013, 5).

Ĕ̆itim Sistemi Yapılandırma Gereksinimleri: “Federal Almanya'da öğrenciler ortaöğretime başlamadan önce kabiliyet ve yeteneklerine göre yönlendirilmektedirler. Bu şekilde öğrencinin kabiliyeti ve yeteneği hangi alanda daha etkili ise öğrenci bu yönde yönlendirilmektedir. Bu şekilde her öğrenciye zevk aldığı ve becerebildiği yönde eğitim verilmektedir ve böylelikle öğrenci sıkılmadan, istekle ders yapmaktadır. Bu nedenle öğrenciler verimli olmaktadırlar. Buna karşılık Türkiye'de böyle bir uygulama yoktur." (Ersoy, 1998, s. 98). "Türk sisteminin beceri ve yetenekleri geliştirebilen, üretken ve verimli bireyler yetiştirecek biçimde yeniden yapılanması bir zorunluluktur." (Gülecen, 2008, s. 139). "Türk eğitim sisteminde öğrenci ilgi, ihtiyaç, beceri ve beklentileri ne yazık ki öncelikli bir tabana oturtulamamıştır." (Yazıcı, 2009).

Eğitimde Yetenek Ölçme ve Değerlendirme Araçlart: “Üniversitelere giriş ÖSYM tarafından hazırlanan merkezi bir sınavda gerçekleştirilmektedir. Ancak bu sinavda öğretmenlik için öğrencilerin uygun yeterliliklere sahip olup olmadıkları ölçülememektedir." (Korkmaz, 2005, s. 157). 
(Uzaktan) Ĕ̆itimde Rehberlik Sistemleri: “Milli Eğitim Temel Kanunu'nda yer almış olmakla birlikte eğitim kurumlarında yöneltme ve danışmanlık hizmetlerinin yetersizliği eğitimdeki en önemli sorunlardan biridir. Öğrencilerin kendilerini yeterince tanıyp ifade edebilmelerine, kendileri ile ilgili kararlar vermelerine olanak verecek gerekli rehberliğin yeterince yapılmadığı gözlenmekte ve araştırmalarla ortaya çıkmaktadır." (Kocatürk, 2006, s. 239). “Öğrencilerin öğrenme sürecine etkin bir biçimde katılımının sağlanması ve herhangi bir sorunla karşılaştıklarında yardım alabilmeleri konusundaki eksiklik uzaktan eğitim sisteminin en dezavantajlı yönü olarak görünmektedir. Ayrıca öğrenciler programı uygulamalı dersler, araç-gereçler ve kendilerine sağlanan geri dönüt konusunda yetersiz bulduklarını ifade etmişlerdir." (Yadigar, 2010).

Eleştirel Yönelimli Eğitim: "Müfredatlarda meslek etiğine yönelik verilen eğitim ile eleştirel bakış açısını yansıtan derslerin eksikliği olmuştur. Geleceğin uzmanlarının eleştirel bakış açısından yoksun olmaları onların analiz yeteneğinin gelişmesi yönündeki en büyük engellerdendir." (Yıldırım, 2015, s. 101).

Rus akademik çalışmalarında yeni medya eğitimi sorunsalı oluşturan unsurlar izleyen başlıklar altında açıklanmaktadır:

Öğretmen-Öğrenci Etkileşimi: “Çoğu öğretmen yaratıc1 metotlara yeniden yön verme konusunda zorluk yaşamaktadır. Öğretmen genellikle öğrencilerle iletişim ve işbirliğine özel bir önem vermez, okuldaki eğitim ve öğretim sürecinde iletişimsel etkileşimin uygun şekilde organize edilmesini sağlamaz." (Возчиков, 1999). "Modern eğitimde öğretmenin monologunun hâla ezici olduğunu gözlemlenmektedir. Yetersizlik durumunu ortaya çıkaran yalnızca öğretmenin yaratıcılık yetenekleri değil, öğrenci statüsünü kazanan okul öncesi çocuklarının öğretmen-öğrenci düzeyinde düzenlenen derslerde bilişsel aktivitesinden kaynaklanan güçlükleridir.” (Дейкина, 2000). “Üniversite öğretmenlerinin kendileri sosyal beceri yeterliklerinine sahip olmalı ve bunları öğrencilere aşılamalıdırlar." (Кильпеляйнен, 2019).

Medya Kültürünün Oluşumu: “Öğrencinin medya kültürünün oluşturulmasında okul öğretmeni ve velinin etkileşimini, sınıf öğretmeninin aile ile amaca 
yönelik çalışmasıyla okulun eğitim alanının genişlemesini ortaya koyan özel bir araştırmaya rastlanılmamıştır." (Недбай, 2006).

Medya Eğitimi: "Bilimde, kitle iletişim araçları çalışanlarının meslekî eğitim sisteminin durumunun ve beklentilerinin araştırıldığı hiçbir monografi ve tez yoktur. Dolayısıyla, gazetecilik eğitiminin terminolojisi ve genel teorisi geliştirilmemiştir." (Фатеева, 2008). "Rusya'daki medya eğitimi durumunu incelediğimizde, bilgi toplumu çağında okul çocuklarının sosyal deneyimlerinin oluşumu sorununun yeterince çalışılmadığı sonucuna vardık. Mevcut durum aşağıdaki nedenlerle açıklanmaktadır: Medya eğitiminin içerik ve hedeflerinin tanımına ilişkin anlaşmazlıklar, problemi çözmek için teknikçi yaklaşımın yaygınlığı, metodolojik desteğin olmaması, birçok öğretmenin yeni bilgi gerçeklerini ve medya eğitimi fikirlerini algılama isteksizliği." (Анайкина, 2011). "Öğretmenlerin ileri düzey medya eğitimlerinin sağlanmasında meslekî gelişim sisteminin yetersiz olmaktadır." (Искаков, 2013).

Öğretmenlerin Multimedya Kullanımı: “Öğretmenlerin sadece medya eğitiminin oluşum sürecine değil, aynı zamanda sınıflarında multimedya kullanımına da hazırlıksız olduğu ortaya çıktı. Ders öğretmenlerinin \%96'sının (Intel'in "Gelecek için Öğretim" kurslarına katılanları) bilgisayarın sağladığ multimedya olanaklarını kullanarak çalışmalarını nasıl oluşturacağını bilmediklerini gösteren veriler elde ettik. Bu kısmen öğretmenlerin meslekî açıdan yeterli olmadıklarına işaret etmektedir." (Ковшарова, 2006.

Öğrencilerin Yeni Medya Okuryazarlığı Düzeyleri: “Günümüzde ne ailenin, ne genel ve meslekî eğitim kurumlarının ne de medyanın öğrencilerin ve gençlerin kişisel gelişimlerinde önemli bir rol oynayan bağımsız ve bilinçli bilgi seçimi yapma becerilerinin öğretimi yapmadığı ortaya çıkmıştır." (Кантор, 2010). "Meslekî eğitim bağlamında güncellenen ve ekonomik bir kategori olarak enformasyonun önemi arttı̆ genç nesli hayata hazırlama sorunu olmasına rağmen, bir üniversite mezunun küresel bilgi alanına girmeye hazır olmadığı bir durumla sık sık karşılaşıуoruz." (Кутькина, 2006).

Yeni Eğitim Teknolojileri: “Şimdiye kadar, üniversitelerin bu amaçlar için tek bir stratejisi yoktur, bilgi teknolojilerini kullanma konuları müfredat ve prog- 
ramlarla zayıf bir şekilde ilişkilidir, eğitim sürecinde uygulamalarının psikolojik ve pedagojik yönleri yeterince çalışılmamış ve üzerinde çalışılmamıştır." (Иванова, 2004). “Еğitim kurumlarının öğretim elemanlarının medya eğitimi için uygun bir materyal, teknik temelin ve mekanizmaların yokluğunda, uzun süredir Rus okullarında medya eğitim teknolojilerinin yaygin pratik yayılımı için yeterli zemin olmadığını belirtmiştir." (Щербакова, 2008).

Rusya'da Yeni Eğitim Sistemi: “Günümüzde bilim adamlan devlet eğitiminde standardının sağlanmayışına ve mezunların eğitim kalitesinin değerlendirilmesine odaklanmaktadırlar." (Журин, 2008). "Önerilen çok sayıda eğitim sistemi projesi, bize göre, derin krizine tanıklık etmekte." (Возчиков, 2007). “Geliştirilmemiş terminoloji ve mevcut gazetecilik eğitimi profesyonel eğitim sistemlerinin oluşturulmasında en önemli engeller arasında yer almaktadır." (Фатеева, 2008).

Yeni Medya Eğitimi Sorunsalı Üzerine Türk ve Rus Bilirkişilerin Görüşlerinin İncelenmesine İlişkin Bulgular

Türk bilirkişilerin konuya ilişkin görüşleri aşağıda verilmiştir:

Mahmut Akgül ve Mustafa Akdă̆: "Batıdaki öncülerine benzer şekilde Türkiye'de de Web 2.0'1 takip ederek başlayan yeni medya eğitimi, günümüz Türkiye'sindeki iletişim eğitiminin en yeni sorunsalı olarak ön plana çıkarmaktadır." (Akgül ve Akdağ, 2017, s. 211).

Zeynep Özarslan: “Türkiye'de yeni medya üzerine yapılan akademik çalışmalarda yeni medya eğitiminin nasıl olması gerektiği, yeni medya müfredatı ya da yükseköğretim politikası geliştirme üzerine çok fazla odaklanılmadığ gözlemlenmiştir. Yükseköğretim Kurulu (YÖK) ulusal tez merkezinde (tez.yok.gov.tr) "iletişim eğitimi" anahtar kelimeleri ile yapılan taramada yükseköğretimdeki iletişim eğitimini inceleyen üç tez (Aslan, 2017; Can, 2017; Yengin, 2017) olduğu ve "medya eğitimi" anahtar kelimeleri ile yapılan taramada, genellikle medya okuryazarlığı eğitimine odaklanıldığı (Seylan, 2008; Koç, 2016; İnan, 2010; Dumlu, 2018; Kutlu, 2018; Ekşioğulları, 2018; Yıldız, 2011; Bakan, 2010; Aslan, 2009) gözlemlenmiştir. "Yeni medya eğitimi” anahtar kelimeleri ile yapılan taramada ise hiçbir sonuç elde edilememiştir. Sonuç 
olarak, ulusal tez merkezindeki verilere göre, yükseköğretimdeki iletişim eğitimi konusunda az sayıda çalışma vardır ve yeni medya eğitimi ise bugüne kadar hiçbir tezde anahtar kelime olarak kullanılmamıştır."(Özarslan, 2019, s. 155).

Hıfzı Topuz: Yeni medya eğitimi sorunsalı konunun önemini daha iyi anlaşılması ve benimsenmesi için "Medya eğitimi projesi bütün iletişim fakültelerinde, öğretmen okullarında ve eğitim fakültelerinde yer almalı ve her şeyden önce bu eğitimi uygulayacak öğretim üyelerinin yetiştirilmesi için seminerler düzenlenmeleridir. Başka ülkelerdeki uygulamaları da yakından izlemek gerekir" (Topuz, 2006, s. 3).

Rus bilirkişilerin konuya ilişkin görüşleri aşağıda verilmiştir:

Aleksandr Fedorov: “21. yüzyılda medya eğitimi, medya ile iletişim kurabilme, yaratıcılığı, iletişim becerileri, eleştirel/demokratik düşünme, medya metinlerini tam anlamiyla algılama, yorumlama, analiz ve değerlendime becerilerini geliştirme ve medya teknolojisini kullanarak kendini ifade etme biçimlerini öğretme yönünde kitle iletişimi yoluyla temellendiren kişilik gelişimi süreci olarak giderek önem kazanmaktadır." (Федоров, 2007, s. 82).

Aleksey Galchenkov: “Günümüzde medya eğitimi, modern okulların önde gelen pedagojik teknolojilerinden biri olup, bireyin kendi etrafındaki dünyaya hâkim olmanın bir araç sistemi olarak tanımlanmaktadır. Modern okuldaki medya eğitimi potansiyeli, medya alanına erken yaşlardan itibaren dâhil olan, ancak ne yazık ki yeterli medya okuryazarlığına sahip olmayan ergenlerin çok yönlü gelişiminde yatmaktadır." (Галченков vе Авдеева, 2019, s. 121).

Tatiana Skudnova ve Maria Paşkova: "Medya eğitimi alanlarını inşa etme metodolojisi ve medyanın büyümekte olan yetişkinlerin üzerindeki etkisinin mekanizmaları henüz oluşum aşamasındadır. Eğitim felsefesi ve medya felsefesi metodolojisi kapsamında medya eğitimi alanı ve medya eğitiminin organize edilmesine ilişkin sorunların sistematik değerlendirmesi, Rus bilimde aktif olarak geliştirilmeye yeni başliyor." (Скуднова ve Пашкова, 2019, s. 197). 


\section{Tartışma}

Günümüzde medya pedagojisinde dünyanın tüm ülkeleri için ortak bir terminoloji yoktur (Скуднова vе Пашкова, 2019, 196). Bilim adamları, medya eğitimi alanını tanımlamak için "medya pedagojisi", "medya eğitimi", "medya kültürü", " medya okuryazarlı̆̆ı" ve "medya yeterliliği'” gibi anahtar kavramlarla farklı seçenekler sunmaktadır. Medya eğitimi geleneğine sahip olan Rusya'da bütün bu kavramları ele alan akademik çalışmalara rastlamak mümkünken, Türkiye'de "medya eğitimi' kavramı ile ilgili bilimsel çalışma yok denilecek kadar azdır. Türkiye'deki bu durum, medya eğitimi kavramının net bir tanımı olmadığı ve bilim alanındaki yerinin belirlenmediğine işaret etmektedir. Rusya'da eğitim ve iletişim fakülteleri arasında süren bu noktadaki tartışmalar, medya eğitiminin 2002 yılında pedagojide yeri almasıyla birlikte sona ermiştir. Bu çalışma kapsamında incelenen Türk akademik araştırmalarda benzer bir tartışmanın olmadığı gözlemlenmiştir. Ayrıca yukarıda belirtildiği kavramlara ek olarak, Türkiye'de akademik çalışmalarında en sık kullanılan terim "medya okuryazarlığı" ve "medya okuryazarlığı eğitimi'dir.

2017 yılında yayınlanan "Medya Okuryazarlığı Alanında Yapılan Araştırmalar: Bir Kaynakça Denemesi" isimli çalışmada, Mehmet Nuri Kardaş ve Şenay Yıldırım ülkemizde 2000 ve 2017 yılları arasında medya okuryazarlığı ile ilgili toplam 308 araştırma yapıldığı tespit etmişlerdir. Makaledeki verilere göre bu çalışmaların 5'i 2000-2005 y1llarında; 18'i 2006; 8'i 2007; 22'si 2008; 14'ü 2009; 20'si 2010; 20'si 2011; 30'u 2012; 59'u 2013; 21'i 2014; 41'i 2015; 36's1 2016; 14'ü ise 2017 yılında yapıldığı belirlenmiştir (Kardaş ve Yıldırım, 2017). Çalışmada en çok araştırmanın yapıldığı türlerin başında "makale"nin ( $\mathrm{f}=137 ; \% 44,48)$ geldiği belirlenmiştir. Makale türündeki çalışmaları "bildiri" ( $\mathrm{f}=106 ; \% 34,41)$, "yüksek lisans tezi" ( $\mathrm{f}=45 ; \% 14.61)$ ve "doktora tezi" ( $\mathrm{f}=11$; \% 3,57)'nin takip ettiği tespit edilmiştir (Kardaş ve Yıldırım, 2017).

Bu çalışmada, kavram alanına göre akademik çalışmaları dağlımı incelenerek, nicel yaklaşımlar bakımından her bir kavram için ne tür farklılıklar olduğu ortaya konulmuştur. Türkiye' de yeni medya ile ilgili çalışmalar son dönemlerde ağırlık kazanmasına rağmen yapılan çalışmaların sayısı azdır. Türkiye'de 255 akademik çalışma kaydedilirken, Rusya'da bu rakam 17 bin 316'ya ulaşmıştır. Bu çalışmanın konusu olan "yeni medya eğitimi" ve "yeni medya eğitimi sorunları" kavramları ele alan yüksek lisans ve doktora tezleri 
Türkiye'de tespit edilmezken, Rusya'da bu araştırma sayısının 386'ya yükseldiği gözlemlenmiştir.

Rusya'da bilimsel çalışmalar üzerine yapılan bir araştırmada 2012-2018 yıllarını kapsayan dönemde medya eğitimi sorunlarına ayrılmış tezlerin oranı, bilimsel uzmanlık "gazetecilik" alanındaki toplam tez sayısının yalnızca yüzde 1'ini oluşturduğu tespit edilmiştir (Исакова, 2019, s. 113). Bu veriler 2008 y1lında Aleksandr Fedorov'un “Медиаобразование вчера и сегодня" ("Medya Eğitimi Dün ve Bugün") isimli çalışmasında yer alan Rusya için medya eğitimi öngörülerini doğrulamamaktadır. Fedorov'un gelecek için öngörüde bulunduğu düşünce; medya pedagojisi, medya eleştirisi ve gazetecilik alanındaki araştırma konularının yakınlaşması devam edeceğini ve medya eğitimi, medya okuryazarlığı ve medya yeterliliği sorunlarıyla ilgili çalışmaların sayısı gittikçe artacağından (Фёдоров, 2009, s. 58) söz etmektedir.

Medya eğitimi konulu bilimsel çalışmalar üzerine yapılan en güncel analizi yine bu yazara aittir. Aleksandr Fedorov, Mart 2020 tarihli “Dissertation Researches on Media Literacy Education in Commonwealth of Independent States (CIS)" ("Bağımsız Devletler Topluluğu'nda (BDT) Medya Okuryazarlığı Eğitimi Üzerine Tez Araştırmaları") adlı eserinde Rusya'da 1992'den 2019 yılına kadar toplam 364 tez savunulduğunu belirtmektedir. Fedorov'un iddiasına göre, son on yılda medya eğitimi sorunlarına ayrılmış tezlerin oranı yüzde 1'ini değil, yüzde 4,5'ini oluşturmaktadır.

Türkiye'de yeni medya eğitimi sorunsalı, medya okuryazarlığı bağlamında yeni okuryazarlıklar konulu yapılan akademik çalışmalarla 2015 yılından itibaren ağırlık kazanmaya başlamıştır. Rusya' daki bu süreç 2014 yılında medya okuryazarlığı kavramının yeniden kavramsallaştırılmasıyla gündeme gelmiştir. Medya pedagojisi, yeni medya eğitimi, medya okuryazarlığı eğitimi, medya ve bilgi okuryazarlığı, medya verimliliği ve bilgi ekonomisi kavramları etrafında tartışılan yeni medya eğitimi sorunların birkaçı aşağıdaki tabloda verilmiştir.

Tablo 9. Türk Akademik Çalışmalarnnda Yeni Medya Eğitimi Sorunsalı

\begin{tabular}{lll}
\hline Ülke & Kavram & Sorun \\
\hline Türkiye & Medya & Yazılımsal altyapı ve donanımsal araçlar üzerinden \\
& Pedagojisi & sanat ve yaratıcılık katarak inşa edilen yeni medya \\
& & yayıncılığının pedagojik ayağında, söz konusu \\
& & derslerin (sanat tasarım ve bilişim) kapsadığı \\
\hline
\end{tabular}


Türk ve Rus Akademik Çalışmalarında Yeni Medya Eğitimi Sorunsalı Üzerine Bir Değerlendirme

\begin{tabular}{|c|c|}
\hline & $\begin{array}{l}\text { alanın sınırlılığı, önemli bir eksiklik olarak görülmektedir (Ak- } \\
\text { gül ve Akdağ, 2017, s.219). }\end{array}$ \\
\hline $\begin{array}{l}\text { Yeni } \\
\text { Medya } \\
\text { Eğitimi }\end{array}$ & $\begin{array}{l}\text { Doğrudan devşirilmiş derslerin yanı sıra iletişim disiplinle- } \\
\text { rine ait bazı dersler, yeni medya kavramıyla bağdaştırılarak } \\
\text { eklektik ve melez bir müfredat ortaya çıkarılmıştır. Bu durum, } \\
\text { yeni medya eğitiminde özgün bir literatürün oluşturulamadı- } \\
\text { ğının somut göstergesidir (Akgül ve Akdağ, 2017, s. 219). }\end{array}$ \\
\hline $\begin{array}{c}\text { Medya } \\
\text { Okuryazarlığı } \\
\text { Eğitimi }\end{array}$ & $\begin{array}{l}\text { Medya okuryazarlığı eğitiminde en tartışmalı olan ve üze- } \\
\text { rinde en çok düşünülmesi gereken konunun, bu dersin ileti- } \\
\text { şim disiplinine dair hiçbir alt yapıya sahip olmayan Sosyal Bil- } \\
\text { giler öğretmenleri tarafından verilmesidir (Çoşkun ve Boz- } \\
\text { kurt, 2018, s. 508). }\end{array}$ \\
\hline
\end{tabular}

Medya okuryazarlığı eğitimindeki sorunlar birçok Türk araştırmacı tarafından incelenmiş ve şu ortak görüşe sahip olmuşlardır: Türkiye'de medya okuryazarlı̆̆ı eğitiminin; sadece ilköğretimin ikinci kademesine sıkıştırılması, haftada iki saat olması, üstelik seçmeli olması, dersi veren öğretmenlerin bu konuda yeterli eğitim almamış olması, ders malzemelerinin yetersizliği hayat boyu geliştirilmesi gereken bir medya okuryazarlığı eğitiminin gereklerini karşılamaktan uzak görünmektedir (Bozkurt ve Çoşkun, 2018, s. 508).

Tablo 10. Rus Akademik Çalışmalarında Yeni Medya Eğitimi Sorunsalı

\begin{tabular}{|c|c|}
\hline Ülke $\quad$ Kavram & Sorun \\
\hline $\begin{array}{l}\text { Rusya Medya } \\
\text { ve Bilgi } \\
\text { Okuryazarlığ1 }\end{array}$ & $\begin{array}{l}\text { Medya ve bilgi okuryazarlığını birleştirme yolları hakkında teorik fikir- } \\
\text { lerin tutarsızlığı ve buna bağlı olarak öğrencilerin medya bilgi okurya- } \\
\text { zarlığı oluşumunun bütünlüğünü ve tutarlığını sağlayan metodolojik } \\
\text { gelişmelerin eksikliği (Гендина ve Косолапова, 2019, s. 189). }\end{array}$ \\
\hline Eğiticilik & $\begin{array}{l}\text { İnsanların medya ve bilgi kültürünü arttırılması amaçlayan farklı mes- } \\
\text { lekleri temsil eden profesyonellerine (öğretmenler, sosyal eğitimciler, } \\
\text { psikologlar, kütüphaneciler, gazeteciler) rehberlik eden ulusal çapta bir } \\
\text { çalışma stratejisinin eksikliği (Гендина ve Косолапова, 2019, s. 190). }\end{array}$ \\
\hline $\begin{array}{l}\text { Medya Bilgi } \\
\text { Verimliliği } \\
\text { Ekonomisi }\end{array}$ & $\begin{array}{l}\text { Medya eğitiminin bölge ekonomisinin gelişimine katkısı sayesinde kü- } \\
\text { resel rekabetçiliğinin korunmasına ve bölgelerde bilgi ekonomisinin ku- } \\
\text { rulmasına katkıda bulunduğu hâlde medya eğitimi potansiyeli yetersiz } \\
\text { kullanıldığı düşünülmektedir (Боговиз, Лобова, Рагулина, Алексеев } \\
\text { ve Гарнова, 2017, s. 9). }\end{array}$ \\
\hline
\end{tabular}

2013 yılında Rus yazar Georgiy Poçeptzov “Новые медиа - старые проблемы" ("Yeni Medya Eski Sorunlar") adlı makalesinde şunları yazmıstrr: "Bugün, film ve televizyondan eğitime kadar hemen hemen her şeyin entelektüel seviyesinde bir düşüş var" (Почепцов, 2013). 2019 yılında Rus bilim adamı Natalya Gendina bulunduğumuz dijital dünyanın en büyük sorunsalı 
dile getitmektedir: "Modern bilginin gücü teknoloji tehlikesi yaratır, insan bilinci ve davranışı insanlıktan çıkarmakla tehdit ediyor. Bu nedenle modern insan medya ve bilgi okuryazarlığı gibi özel bir okuryazarlığa sahip olmalıdır" (Гендина, 2019, s. 181).

\section{Sonuç}

Yeni tekno-kültürün üreticisi ve tüketicisi olan insan, medyanın "yeni" hallerine ayak uydurmak için çaba gösterirken, McLuhan'ın alt sistemlerinde olduğu gibi, çok katmanll, çok etkileşimli ve çelişkilerle dolu toplumsal bir alanda yeni medya okuryazarlığı becerilerine sahip olup olmadığına, yeni nesil teknolojilerini kullanıp kullanmadığına ve yetiştirildiği eğitim sistemi kalitesini sorgulamaktadır. Yeni medya eğitiminde kilitlenen bu gelişmeler, hızlı küreselleşen dünyada gündemin en sıcak konularından biri olmaya başlamıştır. Tüm dünyada olduğu gibi, Türkiye'de ve Rusya' da da yeni medya eğitiminin karmaşık yapısını bilim insanları tarafından mercek altına alınarak, akademik araştırmalarla başlıca sorunları ortaya konulmaya çalışılmıştır.

Bu çalışma kapsamında yapılan içerik analizi ve alanyazın incelemesi, Türk ve Rus akademik çalışmalarında yeni medya eğitimi sorunsalının yetersiz ve yüzeysel olarak ele alındığı tespit edilmiştir. İnceleme sonuçlarına göre, elektronik teknoloji çağında yeni medya eğitimine artan talep, sürekli değişen beklenti ve ihtiyaçlar sonucu, yeni medya okuryazarlığı, yeni nesil teknolojileri ve yeni eğitim sistemlerinden kaynaklanan sorunlarına odaklanan çalışmaları alanı doğmuştur. Türkiye'de "yeni medya eğitimi" sık kullanılan bir kavram olmasına rağmen, akademik çalışmalarında nadir olarak açıklanmaktadır. Bu çalışmada "yeni medya eğitimi" başlıklı hiç bir tez bulunmadığı ve alandaki yaşanan sorunlara değinen sadece üç bilimsel makale olduğu sonucuna ulaşılmıştır. Rusya'da yeni medya eğitimi konusunu ele alan akademik çalışma sayısının yüksek olmasına rağmen, doğrudan yeni medya eğitimi sorunları inceleyen araştırmaların sayısı göreceli oldukça azdır.

Bu çalışmanın özünü en iyi şekilde açıklayan "yeni medya eğitimi sorunsalı üçgeni" konuya ışık getireceğini düşündügüunden dolayı, Türkiye'de ve Rusya'da yeni medya okuryazarlığı, yeni nesil teknolojileri ve eğitim sistemleri üzerine yapılan araştırmaları tespit edilmeye ve içerik analizi ile incelenmeye çalışılmıştır. 
Türkiye'de yeni medya eğitimi sorunsalı medya okuryazarlı̆̆ 1 dersin verimsizliği, yeni medya eğitiminin pedagojik ayağını geliştiren uygun bir müfredat yoksunluğu ve yeni medya eğitimi araştırma alanında çığır açan, ufuk kazandıran eserlerin eksikliği etrafında yoğunlaşmaktadır. Alanda az akademik çalışma yapılmakla birlikte, "yeni medya eğitimi sorunsalı üçgeni"ndeki yer alan yeni eğitim teknolojileri ve yeni eğitim sistemleri kavramlarla ilgili yapılan çalışmaların bulunmaması, konuyu yenilikçilik çerçevesinde incelenmesi ihtiyacını doğurmaktadır.

Rusya'da yeni medya eğitimi kapsamı oluşturan birçok kavram ve bu kavramlarla ilgili araştırmalar bulunmasına rağmen, "yeni medya eğitimi sorunları" başlıklı bir tez çalışması bulunmamaktadır. Bununla birlikte, alandaki sorunları "yeni" ön eki kullanılmadan ikinci ya da üçüncü başlıklarla ortaya konulmaktadır. Yapılan tez çalışmalarında birçok Rus araştırmacı gazeteciliğin sistemik krizinden bahsetmektedir. Araştırmacılar, gazetecilikte yeni eğilimler ve yenilikçi araçların yayılması Rusya'daki medya endüstrisi için uzman yetiştirmekte mevcut okulun geleneksel tutumlarını değiştirdi, ancak modern koşullarda eğitimleri için yeni ilkeler yaratmadığının altını çizmektedir. Medya eğitimi konusunda önemli bir tecrübeye sahip olan Rusya'da nitelikli öğretmen sorunu gündemdedir.

Sonuç olarak, Türk akademik çalışmalarında yeni medya eğitimi ve özellikle yeni medya eğitimi sorunsalının pedagojik boyutunun yeterince ele alınmadığından söz edilirken, Rus tezlerin ezici çoğunluğu pedagoji alanıyla ilgilidir ve bu çalışmalarda medya eğitiminin üretken işlevini medya olgusuyla bağlantılı olarak araştırılmamaktadır. 


\title{
EXTENDED ABSTRACT
}

\section{An Evaluation on the Problem of New Media Education in Turkish and Russian Academic Studies}

\author{
Olga Untila Kaplan \\ Istanbul Medipol University
}

As the producer and consumer of the new techno-culture, while striving to keep up with the "new" states of the media, as in the sub-systems of McLuhan, whether they have new media literacy skills in a multi-layered, multi-interactive and contradictory social field, It questions whether it uses its technologies and the quality of the education system in which it was trained. These developments, which are locked in new media education, have become one of the hottest topics on the agenda in the rapidly globalizing world. As in all the world, the complex structure of the new media education in Russia and in Turkey taking scrutinized by scientists, has tried to put forward the main problems with academic research.

Although some researches have been conducted on new media education at national level in academic studies that are open to open access, it is seen that there are not enough studies and examinations on the subject such as the new media education problem in Turkish and Russian academic studies. In this study, to determine academic studies and new media education in Russia, Turkey and aims to be evaluated comparatively common problems in this area.

In this study, in Turkey Higher Education Council (YÖK) National Thesis Center (Scientific Electronic Library of Theses and Abstracts https://tez.yok.gov.tr/ulusaltezmerkezi/)'n and in Russia (I dissercat.co) 's A total of 539 academic studies, including 159 Turkish and 380 Russian, written on new media education between 1988 and 2020 on their digital pages were examined. "New media education problematic triangle" was formed for the analysis of the studies determined within this scope. Turkey and affected by each other in new media education in Russia and the problems evident in winning digital conversion process is examined under three main headings: (1) New media literacy training; (2) New generation (communication / education) technologies; (3) New education systems. 
This explains the essence of the work in the best way "new media training problematic triangle" because he thinks will bring issues to light, new media literacy in Turkey and Russia, have been studied with next-generation technologies and to identify research on educational systems and content analysis. This triangle, which creates the new media education problem, reflects the locked problems in the new media literacy education of individuals in the digital world.

In the findings section of the research, there are analyzes and findings obtained on academic studies on the new media education problematic on Turkish and Russian digital platforms. The academic studies analyzed according to the problem groups in the "new media education problematic triangle" were examined in terms of different variables and the elements that constitute the new media education problematic were explained under various headings with the method of comparison. The most important of these are; new media literacy levels of students, new media literacy levels of teachers, new educational technologies, new communication technologies in distance education system, teachers' use of multimedia and media education.

Content analysis and literature review conducted within the scope of this study revealed that the problematic of new media education in Turkish and Russian academic studies was handled insufficiently and superficially. According to the results of the analysis, as a result of the increasing demand for new media education, constantly changing expectations and needs in the electronic technology age, the field of studies that focus on the problems arising from new media literacy, new generation technologies and new education systems has emerged. In Turkey, the "new media training" Although it is a concept used frequently been described as rare in academic studies. In this study, it was concluded that there were no thesis titled "new media education" and only three scientific articles addressing the problems experienced in the field. Despite the high number of academic studies dealing with the issue of new media education in Russia, the number of studies directly examining new media education problems is relatively low.

In this study, by examining the distribution of academic studies according to the concept area, what kinds of differences exist for each concept in terms of quantitative approaches have been revealed. Despite gaining weight in recent studies related to new media in Turkey Few of the studies. 255 academic studies recorded in Turkey, this figure has reached 17 thousand 316 in Russia. 
This field of study is "new media education " and" new media education problems' concept addressing graduate and identify doctoral dissertations in Turkey edilmezken, the number of this research in Russia has been observed to rise to 386'y. According to the results of the researches on scientific studies in Russia, it has been determined that the rate of theses devoted to media education problems constitutes 1 percent of the total number of theses in the field of scientific expertise "journalism". According to some researchers, this rate is not 1 percent, but 4.5 percent.

New media training problematic media literacy course inefficiency in Turkey, according develops the pedagogical feet of new media curriculum deprivation and new media training groundbreaking research area is focused around the lack of work-saving horizon. Although there are few academic studies in the field, the absence of studies on new educational technologies and new education systems concepts in the "new media education problematic triangle" raises the need to examine the subject within the framework of innovation.

Although there are many concepts that constitute the scope of new media education in Russia and there are researches on these concepts, there is no thesis study titled "new media education problems". However, the problems in the field are presented under the second or third headings without using the "new" prefix. In the thesis studies, many Russian researchers talk about the systemic crisis of investigative journalism. Researchers underline that new trends and the spread of innovative tools in journalism have changed the traditional attitudes of the current school to train experts for the media industry in Russia, but underline that it does not create new principles for their education in modern conditions. In Russia, which has a significant experience in media education, the problem of qualified teachers is on the agenda.

As a result, it is mentioned that the pedagogical dimension of new media education and especially the new media education problem is not adequately addressed in Turkish academic studies, while the vast majority of Russian theses are related to the field of pedagogy and the productive function of media education in these studies is not investigated in relation to the phenomenon of media. 


\section{Kaynakça / References}

Akgül, M. ve Akdağ. M. (2017). Türkiye'de yeni medya eğitimi üzerine niceliksel bir betimleme. Erciyes Illetişim Dergisi "Academia", 5(1), 210-220.

Анайкина, Ю. С. (2011). Формирование социального опьта стариеклассников в проиессе медиаобразования. Yüksek Lisans Tezi, GenişletilmişÖzet, Kostroma Nekrasov Devlet Üniversitesi, Kostroma.

Aygün, H. A. (2009). Yeni ilköğretim programınn uygulanmastyla eğitim teknolojileri kullanımına ilişkin öğretmen görü̈sleri: İstanbul İli Ümranye İlçesi örneği. Yüksek Lisans Tezi, Sakarya Üniversitesi, Sakarya.

Боговиз, А. В., Аобова, С. В., Рагулина, Ю. В., Алексеев, А.Н., vе Гарнова, В. Ю. (2017). Медиаобразование в регионах России: проблемы и перспективы. Медиаобразование. Media Education. 3, 7-14.2 Ocak 2020 tarihinde https://cyberleninka.ru/article/n/mediaobrazovanie-v-regionah-rossii-problemy-i-perspektivy adresiden erişilmiştir.

Bozkurt F., ve Çoşkun D. (2018). 21. yy okuryazarlı̆̆: Öğretmen adaylarının medya algilarına genel bir bakış, Erciyes IIletişim Dergisi, 5(4), 493-511.

Çağlar, E. (2012). Yeni medya dolayıml eğitim ortammda fatih projesi öğretmenlerinin pedagojik uygulamalarnnm uluslararası̈̈̆retmen standartlar ile karşılaştırlması. Yüksek Lisans Tezi, Kadir Has Üniversitesi, İstanbul.

Çobanoğlu, A. O. (2018). Öğretmenlerin eğitim teknolojileri kullanm durumlan ile sosyal medya alşskanliklan arasındaki ilişki. Yüksek Lisans Tezi, Çanakkale Onsekiz Mart Üniversitesi, Çanakkale.

Dieuzeide, H. (1984). Communication and education: Media education. Ed. Z. Morsy, United Nations Educational, Scientific and Cultural Organization, Paris. 2 Şubat 2020 tarihinde https://unesdoc.unesco.org/ark:/48223/pf0000062522 adresinden erişilmiştir.

Дейкина, А. Ю. (2000). Развитие познавательных интересов доикольников в проиессе медиаобразования. Yüksek Lisans Tezi, Genişletilmiş Özet. Barnaul Devlet Pedagoji Üniversitesi, Barnaul.

Elitaş, T. (2017). Uzaktan eğitim lisans sürecinde yeni iletişim teknolojileri:Atatürk Üniversitesi uzaktan eğitim merkezi. Doktora Tezi, Marmara Üniversitesi, İstanbul.

Engin, M. (2013). Üniversitelerde teknoloji yoğun uzaktan eğitim sistemlerinin üretim, uygulama ve yönetim süreçlerinin incelenmesi. Doktora Tezi, Ankara Üniversitesi, Ankara.

Ersoy, H. (1998). Türk ve Alman eğitim sistemlerinde orta öğretimlerin ve müfredatlarnnın karşılaştırlması. Yüksek Lisans Tezi, Sakarya Üniversitesi. 
Фатеева, И. А. (2008). Журналистское образование в России: теория, история, современная практика. Doktora Tezi. Genişletilmiş Özet, Çelyabinsk Devlet Üniversitesi, Ekaterinburg.

Фedorov F., ve Levitskaya A. (2020). Dissertation researches on media literacy education in Commonwealth of Independent States (CIS), Media Education (Mediaobrazovanie), 60(1): 63-99. doi:10.13187/me.2020.1.63

Фёдоров, А. В. (2009). Медиаобразование вчера и сегодня. Moskova, МОО ВПП ЮНЕСКО «Информация для всех». 14 Mart 2020 tarihinde http://window.edu.ru/catalog/pdf2txt/782/62782/32886 adresinden erişilmiştir.

Фёдоров, А. В. (2007). Состояние медиаобразования в мире: мнения экспертов. Медиаобразование, 1, 44-82. 15 Mart 2020 tarihinde https://mediaeducation.ucoz.ru/load/stati mediaobrazovanie mediagramotnost mediakompetentnost mediapedagogika/4 adresinden erişilmiştir.

Фёдоров, А. В., vе Левицкая, А. А. (2018). Массовое медиаобразование в России на современном этапе, Медиаобразование, 2, doi:10.13140/RG.2.2.28598.60486

Галченков, А. С., vе Авдеева, Г. В. (2019). Реализация интегрированного медиаобразования в школе. Современное состояние медиаобразования 6 России в контексте мировых тенденциий Konferans Kitabl, Taganrog. 25 Mart 2020 tarihinde https:/www.researchgate.net/publication/337089759 Sovremennoe sostoanie mediaobrazovania $\mathrm{v}$ Rossii v kontekste mirovyh tendencij_k_65letiu pocetnogo prezidenta_Associacii_kinoobrazovania i mediapedagogiki Rossii professora AV Fedorova mat mezdunarod adresinden erişilmiştir.

Gegeoğlu, Ş. (2014). Ortäŏgretim Okullarnndaki Öğretmenlerin Mesleki Alanda Eğitim Teknolojilerini Kullanma Düzeylerinin İncelenmesi. Yüksek Lisans Tezi, İstanbul Aydin Üniversitesi, İstanbul.

Genel, M. G. (2015). Yeni medya araştırmalan 1. güncel tartışmalar ekseninde. Bursa: Ekin Basım Yayın Dağıtım.

Гендина, Н. И. ve Косолапова, Е.В.(2019). Медийно-информационная грамотность в структуре профессиональной подготовки педагогов, журналистов, библиотекарей, Вестник КемГУКИ, 46, 180-194, DOI: 10.31773/2078-1768-2019-46-180-194

Görgülü Aydoğdu, A. (2015). Eleştirel farkındalık yaratmada yeni medya okuryazarlı̆̆ı ve yeni medya bilinci üzerine bir inceleme. Doktora Tezi. Gazi Üniversitesi, Ankara.

Göysarı, M. (2016). A comparative loock at media literacy education in Turkey focusing on the shift to a more critical approach and new media updates in the curriculum. Yüksek Lisans Tezi, Kadir Has Üniversitesi, İstanbul. 
Gülecen, S. (2008). Afganistan ve Türkiye eğitim sistemlerinin karşılaştırmalı olarak incelenmesi. Yüksek Lisans Tezi, Fırat Üniversitesi, Elazığ.

Hacısalihoğlu, H. (2008). Ticaret meslek liselerinde görev yapan öğretmenlerin eğitim teknolojilerini kullanım düzeylerini belirlemeye yönelik bir araştırma. Yüksek Lisans Tezi, Gazi Üniversitesi, Ankara.

Hansu, E. (2019). Yeni medya okuryazarlı̆̆ı açısından ortaöğretim üzerinde ampirik bir çalışma. Yüksek Lisans Tezi. Üsküdar Üniversitesi, İstanbul.

Işkın, P. (2015). Öğretmen görüşlerine göre yenimedya okuryazarlı̆̆ı programı. Yüksek Lisans Tezi, Ondokuz Mayıs Üniversitesi, Samsun.

Иванова, Н. А. (2004). Инновационная технология обучения профессионального ориентированому иноязичнму общениюв контексте медиаобразования. Yüksek Lisans Tezi. Genişletilmiş Özet, Ticaret ve Ekonomi Üniversitesi, Voronej.

Искаков, Б. А. (2013). Развитие медиакомпетентности учителей в условиях ресурсного ценнтра. Yüksek Lisans Tezi. Genişletilmiş Özet, Doğu Kazakistan Devlet Üniversitesi, Barnaul.

Исакова Т. Б. (2019). Освещение проблем медиаобразования в научных трудах. Часть 2. Научные исследования в области медиаобразования в России в период 2012-2018 гт., Вестник Волжского университета имени В. Н. Татищева, 1, 2, 111-120. 3 Nisan 2020 tarihinde https://cyberleninka.ru/journal/n/vestnik-volzhskogo-universiteta-im-v-n-tatischeva?i=1045314 adresinden erişilmiştir.

Журин, А. А. (2004). Интеграциия медиаобразования с курсом химии средней общеобразовательной икольл. Doktora Tezi. Genişletilmiş Özet, Devlet Bilim Kurumu, Rusya Eğitim Akademisi İçerik ve Yönetim Yöntemleri Enstitüsü, Moskova.

Кантор, А. Р. (2010). Телевизионное образование как фактор развития информационной культуры учащейся молодежи в современных условиях. Yüksek Lisans Tezi. Genişletilmiş Özet, Ural Devlet Üniversitesi, Ekaterinburg.

Karasar, Ş. (1999). Sanal yüksekeğitim: Yeni iletişim teknolojilerinden internetin kullanımı. Doktora Tezi Özeti, Anadolu Üniversitesi, Eskişehir.

Kardaş, M. N., ve Yıldırım, Ş. (2017). Medya okuryazarlığı alanında yapılan araştırmalar: Bir kaynakça denemesi. Yüzüncü Yıl Üniversitesi Sosyal Bilimler Enstitüsü Dergisi, 1, 34. 22 Nisan 2020 tarihinde http://www.yyusbedergisi.com/dergiayrinti/medya- okuryazarligi-alaninda-yapilan-arastirmalar-bir-kaynakcadenemesi_127 adresinden erişilmiştir. 
Килыпеляйнен, Е. С. (2019). Трансформацчия профессиональных компетенциий журналиста в период цъифровизацзии медиапространства. Doktora Tezi. Genişletilmiş Özet, Rusya Halkların Dostluğu Üniversitesi, Moskova.

Kocatürk, F. (2006). AB ülkelerinde mesleki eğitim sistemlerinde ilişkin yaklaşımlar ve Türkiye için uyum analizi. Yüksek Lisans Tezi, Gazi Üniversitesi, Ankara.

Koçak, A. ve Arun, Ö. (2006). İçerik analizi çalışmalarında örneklem sorunu. Selçuk Üniversitesi İletişim Fakültesi Dergisi, 4(3), 21-28, 12 Mayıs 2020 tarihinde https://dergipark.org.tr/tr/download/article-file/177956 adresinden erişilmiştir.

Korkmaz, T. (2005). Türkve İngiliz eğitim sistemlerinin karşılaştırlması.Yüksek Lisans Tezi, Uludağ Üniversitesi, Bursa.

Korucu, A. T. (2016). Web 2.0 teknolojilerini kullanma sıklığının ders başarısı üzerindeki etkisine yönelik öğretmen görüşleri. Eğitim ve Öğretim Araştırmalan Dergisi, 5, 379-394.

Ковшарова, Т. В. (2006). Формирование медиаобразованности старшеклассников в эколого-информационном педагогическом пространстве урока. Yüksek Lisans Tezi. Genilşetilmiş Özet, İrkutsk Eğitimcilerin İleri Eğitim Enstitüsü, İrkutsk.

Кутькина, О. П. (2006). Педагогические условия формирования медиакомпетентности будущих библиотечно-информационных специиалистов. Yüksek Lisans Tezi. Genişletilmiş Özet, Barnaul Devlet Pedagoji Üniversitesi, Barnaul.

Недбай, В. В. (2006). Формирование медиакультуры младьшегоподростка. Yüksek Lisans Tezi. Genişletişmiş Özet, Krasnoyarsk Devlet Pedagoji Üniversitesi, Krasnoyarsk.

Ozan, C. (2009). İlköğretim sını öğretmenlerinin eğitim teknolojileri açısından yeterlilikleri: Erzurum İli örneği. Yüksek Lisan Tezi, Atatürk Üniversitesi, Erzurum.

Özarslan, Z. (2019). Türkiye' de Lisans Düzeyindeki Yeni Medya Eğitimi ve Sektör Beklentileri Üzerine Bir Değerlendirme, Moment Dergi. Hacettepe Üniversitesi İletişim Fakültesi Kültürel Çalışmalar Dergisi, 6(1), 150-175. 30 Mayıs 2020 tarihinde https://dergipark.org.tr/tr/download/article-file/764452 adresinden erişilmiştir.

Пашинян, И. (2012). Контент-анализ как метод исследования: Достоинства и ограничения, Научная периодика проблемь и решения, 3(9) https://www.researchgate.net/publication/286253695 Kontent- analiz_kak_metod_issledovania_dostoinstva_i_ogranicenia

Почепцов, Г. (2013). Новые медиа-старые проблемы. Пси Фактор, 1 Haziran 2020 tarihinde https://psyfactor.org/lib/newmedia4.htm adresinden erişilmiştir. 
Schaeffer, P. (1984). Mass media and the school: Descartes or McLuchan?. Ed. Z. Morsy, Media Education, United Nations Educational, Scientific and Cultural Organization. Paris, 16 Haziran 2020 tarihinde https://unesdoc.unesco.org/ark:/48223/pf0000062522 adresinden erişilmiştir.

Selçuk, Z., Palancı, M., Kandemir, M. ve Dündar, H. (2014). Eğitim ve bilim dergisinde yayınlanan araştırmaların eğilimleri: İçerik analizi. Eğitim ve Bilim, 39(173). 430-453. 30 Kasim 2020 tarihinde http://egitimvebilim.ted.org.tr/index.php/EB/article/view/3278 adresinden erişilmiştir.

Скуднова, Т. Д, ve Пашкова, М. Н. (2019). Медиаобразование и медиавоспитание в Испании, Современное состояние медиаобразования в России в контексте мировых тенденциий. Konferans Kitabı, Taganrog. 28 Haziran 2020 tarihinde https://www.researchgate.net/publication/337089759 Sovremennoe sostoanie mediaobrazovania_v_Rossii_v_kontekste mirovyh tendencij_k_65letiu pocetnogo prezidenta Associacii kinoobrazovania i mediapedagogiki Rossii professora AV Fedorova mat mezdunarod adresinden erişilmiştir.

Topuz, H. (2005). Medya eğitimi: Medya çözümlemesi. Ed. Türkoğlu, N. I. Uluslararası Medya Okuryazarlı̆̆ı Konferansı Bildiri Özetleri Kitapçı̆̆ı 23-25 Mayıs 2005, İstanbul.

Untila Kaplan, O. (2020). Medya Sağlık Okuryazarlığında Küresel Ortaklık Arayışları, İstanbul Ticaret Üniversitesi Sosyal Bilimler Dergisi, 37, 697-731.

Возчиков, В.А. (1999). Развитие коммуникативных умений студентов педвуза средствами журналистик. Yüksek Lisans Tezi. Genişletilmiş Özet, Barnaul Devlet Pedagoji Üniversitesi, Barnaul.

Возчиков, В.А. (2007). Философия образования и медиакультура информационноно общества. Doktora Tezi. Gemişletilmiş Özet, Rusya Herzen Devlet Pedagoji Üniversitesi, Sankt-Peterburg.

Щербакова, М. А. (2008). Формирование теоретических способностей учащцихся стариего школьного возраста при реализацчии медиаобразования. Yüksek Lisans Tezi. Genişletilmiş Özet, Kemerovo Devlet Üniversitesi, Kemerovo.

Yavuz, K. (2018). Investigation of university students' new media literacy Levels. Yüksek Lisans Tezi, Yeditepe Üniversitesi, İstanbul.

Yazıcı, İ. (2009). Türk Ĕgitim Sistemi İle Kanada Eğitim Sistemlerinin Karşılaştırılması, Yüksek Lisans Tezi. Yeditepe Üniversitesi, İstanbul.

Yadıgar G. (2010). Uzaktan eğitim sistemlerinin etkinliliğinin değerlendirilmesi: Gazi Üniversitesi bilişim sistemleri uzaktan eğitim tezsiz yüksek lisans programı örneği. Yüksek Lisans Tezi, Gazi Üniversitesi, Ankara. 
Yengin, D. (2014). Yeni Medya ve Dokunmatik Toplum, İstanbul: Derin Yayınları.

Yıldırım, İ. E. (2015). Akademisyenlerin ve Öğrencilerin Gözünden Üniversitedeki Halkla İlişkiler Eğitimi: Romanya ve Türkiye Eğitim Sistemlerinin Karşlaştırlması. Yüksek Lisans Tezi, Ankara Üniversitesi, Ankara.

\section{Kaynakça Bilgisi / Citation Information}

Untila Kaplan, O. (2021). Türk ve Rus akademik çalışmalarında yeni medya eğitimi sorunsalı üzerine bir değerlendirme. OPUS-Uluslararası Toplum Araştırmaları Dergisi, 17(35), 2290-2322. DOI: 10.26466/opus.798847 